\title{
Natural and improved pastures on growth and reproductive performance of Hereford heifers
}

\author{
Antonio Augusto Galarza Rosaํㅜ, Ricardo Zambarda Vaz², José Fernando Piva Lobato³
}

\author{
1 Programa de Pós-Graduação em Zootecnia - Faculdade de Agronomia-UFRGS \\ 2 Universidade Regional Integrada do Alto Uruguai e Missões - Santiago Campus. \\ ${ }^{3}$ Departamento de Zootecnia - Faculdade de Agronomia Caixa Postal 15100, 91.501-970, Porto Alegre, RS.
}

\begin{abstract}
This study evaluated yearling growth and reproductive performance of Hereford heifers at 24-26 months of age grazing on natural pastures at two stocking rates during winter and spring, associated or not to improved natural pastures. Heifers were classified according to three weight groups (Light, Medium and Heavy) and randomly distributed into four feeding management practices: $0.6 \mathrm{AU}$ ( 1 animal unit $=450-\mathrm{kg}$ body weight $)-$ heifers on natural pastures at a stocking rate of $0.6 \mathrm{AU} / \mathrm{ha}$; $0.8 \mathrm{AU}$ - heifers on natural pastures at a stocking rate of $0.8 \mathrm{AU} / \mathrm{ha} ; 0.6 \mathrm{AUI}$ - heifers on natural pastures at a stocking rate of $0.6 \mathrm{AU} / \mathrm{ha}$ and on improved natural pastures between Sept $1^{\text {st }}$ and Nov $1^{\text {st }} ; 0.8 \mathrm{AUI}$ - heifers on natural pasture at a stocking rate of $0.8 \mathrm{AU} / \mathrm{ha}$ and on improved natural pastures between Sept $1^{\text {st }}$ and Nov $1^{\text {st }}$. The stocking rate of 0.8 AU resulted in significant weight loss during winter months (-0.138 and $-0.356 \mathrm{~kg}$ for 0.6 and $0.8 \mathrm{AU}$, respectively). Heifers grazing during the spring on improved natural pastures presented higher weight gain before the breeding season and higher body weight and body condition score in the beginning and end of the breeding season in relation to those grazing only on natural pastures. Heifers kept at $0.6 \mathrm{AU} / \mathrm{ha}$ obtained $69.7 \%$ pregnancy rate, which was significantly higher than the $54.2 \%$ of those managed at $0.8 \mathrm{UA} / \mathrm{ha}$. Heifers grazing on improved natural pastures during the spring achieved $83.8 \%$ pregnancy rate, whereas those maintained on natural pastures achieved only 40.2\%. Light and medium heifers lost less weight during the winter as compared with the heavy ones, but weight differences between groups remained until the end of the breeding season. Heavy heifers have higher pregnancy rates. Heifers submitted to lower stocking rate and those grazing on improved natural pastures conceive earlier.
\end{abstract}

Key Words: body condition, live weight, pregnancy, stocking rate, weight gain

\section{Introduction}

Reducing age at first breeding is one of the main goals of productive beef cattle production systems. Breeding heifers and slaughtering steers at two years of age, Pötter et al. (1998) obtained $28 \%$ outcome rate.

However, first breeding at two days of age is not achieved in all farms in the state of Rio Grande do Sul and in Brazil. The wide range of soil types and the lack of good management practices of forage resources and of the use of improved pastures (Pereira Neto et al., 1999), as well as the lack of good health practices hinder the achievement of that goal.

Among the low-cost practices to improve this scenario, alternative practices can be employed, such as adjusting natural pasture allowance (Neves et al., 2009) and using winter-spring pasture, allocating pasture production and offer according to the requirements of growing and prebreeding heifers (Lobato, 2003). Identifying the need to make such decisions during the macro-processes identified in production systems (Rosado Júnior \& Lobato, 2009) rather posteriorly is critical for the establishment of high productivity in beef cattle production (Beretta et al., 2002; Rosado Júnior \& Lobato, 2010).

Farmers need to understand the association between the cattle frame of their herds and stocking rates and management practices of natural and improved pastures to increase the efficiency of their production systems.

This study aimed at evaluating the effects of two stocking rates of yearling Hereford heifers maintained on natural pastures during winter and spring until first breeding at 24-26 months of age, the responses of one third of these heifers grazing on improved natural pastures in September and October, and the effects of body weight (Light, Medium, and Heavy) on reproductive performance.

\section{Material and Methods}

The experiment was carried out at Xiriscal Farm, located at $30^{\circ} 44^{\prime} 676^{\prime \prime}$ South, $54^{\circ} 47^{\prime} 941^{\prime \prime}$ West and at $183 \mathrm{~m}$ of altitude, in the municipality of Dom Pedrito, RS, Brazil, district of Campo Seco, in the geographic region called 
Campanha, during the period of June $1^{\text {st }}, 2008$ to February 28, 2009.

Two hundred forty-two Hereford heifers, with 20 months of age, on average, at the beginning of the experiment were randomly distributed in the following pasture management practices:

$0.6 \mathrm{AU}-81$ heifers grazing on natural pastures with $1295 \mathrm{~kg}$ of DM initial allowance, stocking rate of $0.6 \mathrm{AU} / \mathrm{ha}=$ $270 \mathrm{~kg} / \mathrm{ha}$ (Animal Unit (AU) $=450-\mathrm{kg}$ body weight) between June $1^{\text {st }}$ and Nov $1^{\text {st }}, 2008$;

$0.8 \mathrm{AU}-81$ heifers grazing on natural pastures with $833 \mathrm{~kg}$ of DM initial allowance, stocking rate of $0.8 \mathrm{AU} / \mathrm{ha}=$ $360 \mathrm{~kg} / \mathrm{ha}$ between June $1^{\text {st }}$ and Nov $1^{\text {st }}, 2008$;

0.6 AUI - 40 heifers grazing on natural pastures with $1295 \mathrm{~kg}$ of DM initial allowance, stocking rate of $0.6 \mathrm{AU} / \mathrm{ha}=$ $270 \mathrm{~kg} / \mathrm{ha}$ between June $1^{\text {st }}$ and Aug 31, and then grazing on improved natural pastures between Sept $1^{\text {st }}$ and Nov $1^{\text {st }}, 2008 ;$ and

0.8 AUI - 40 heifers grazing on natural pastures with $833 \mathrm{~kg}$ of DM initial allowance, stocking rate of 0.8 $\mathrm{AU} / \mathrm{ha}=360 \mathrm{~kg} / \mathrm{ha}$ between June $1^{\text {st }}$ and Aug 31, and then grazing on improved natural pastures between Sept $1^{\text {st }}$ and Nov $1^{\text {st }}, 2008$.

Animal performance on natural pastures was evaluated between June $1^{\text {st }}$ and Aug 31, 2008, in two 160-ha paddocks where summer-cycle species (Andropogon lateralis, Desmodium incanum, Paspalum dilatatum, Paspalum notatum and Trifolium polimorphum) predominated. Both paddocks presented similar water distribution, woods, topography, salt bunkers, and were separated by conventional wire fences. Heifers grazed on these paddocks between June $1^{\text {st }}$ and Aug 31, 2008. On Aug 31, 40 heifers from each paddock were randomly chosen and placed in paddocks with natural pastures improved by the introduction of ryegrass (Lolium multiflorum Lam), white clover (Trifolium repens) and birdsfoot trifoil (Lotus corniculatus cv. São Gabriel) until Nov $1^{\text {st }}$, 2008. Heifers grazed until Nov $1^{\text {st }}, 2008$ as a single group at a stocking rate of $0.7 \mathrm{AU} / \mathrm{ha}$ $(315 \mathrm{~kg} / \mathrm{ha})$. Heifers remaining on natural pastures grazed after Nov $1^{\text {st }}, 2008$ as a single group at a stocking rate of
$0.7 \mathrm{AU} / \mathrm{ha}$, which was obtained by the inclusion of other heifers of the farm.

During the first 45 days of the breeding season, started on Nov 15, 2008, heifers in estrus were submitted to artificial insemination. On the next 21 days, until Jan 20, 2009, natural breeding was used with bulls that were previously approved in libido tests and andrological examination, at a ratio of 1 bull:50 heifers. Pregnancy diagnosis by ultrasound was performed 30 days after the end of the breeding season.

Forage allowance estimates were regularly estimated when heifers were weighed, through the comparative method of Haydock \& Shaw (1975). Pasture samples were collected, identified according to collection day, weighed and analyzed for crude protein (CP) and neutral detergent fiber (NDF) using the methods described by the AOAC (1984) in the Laboratório de Nutrição Animal da Escola de Agronomia, UFRGS (Table 1).

Heifers were weighed after 12 hours of solid and liquid fasting at average intervals of 28 days. Body weight changes were determined as weight differences between weighings, divided by the number of days between weighings. At the time of weight measurements, body condition scores were attributed (BCS; Lowman et al., 1973), according to a 1-5 scale, where $1=$ very thin and $5=$ very fat.

Heifers were classified according to weight groups as: Light (average weight: $241 \mathrm{~kg}$; range: $215-250 \mathrm{~kg}$ ), Medium (average weight: $259 \mathrm{~kg}$; range: 251-269 kg) and Heavy (average weight: $286 \mathrm{~kg}$; range: $270-309 \mathrm{~kg}$ ).

The parameter conception date of 2008 was estimated considering the calving date in 2009 minus 285 days, which corresponds to the average pregnancy duration in Hereford cows (Sawyer et al., 1991).

Data were analyzed according to a completely randomized experimental design, with the effect of pasture (natural pasture or improved natural pasture) nested within previous stocking rate (high or low stocking rates), determining the four forage management systems described above.

The analysis of the three weight groups did not show any interactions with the other effects $(\mathrm{P}>0.05)$, and therefore, the interactions were removed from the model.

Table 1 - Forage mass and crude protein and neutral detergent fiber percentages of the pastures grazed during the experimental period

\begin{tabular}{|c|c|c|c|c|c|}
\hline \multirow[t]{2}{*}{ Management system } & \multirow[t]{2}{*}{ Period } & \multicolumn{2}{|c|}{ Forage mass $(\mathrm{kg} / \mathrm{ha} \mathrm{DM})$} & \multirow[t]{2}{*}{ Crude protein $(\%)$} & \multirow[t]{2}{*}{ Neutral detergent fiber $(\%)$} \\
\hline & & Mean & Range & & \\
\hline \multirow[t]{2}{*}{$0.6 \mathrm{AU}$} & June-August & 1183 & $1123-1295$ & 6.77 & 68.55 \\
\hline & September-November & 1340 & $1240-1434$ & 5.80 & 71.65 \\
\hline \multirow[t]{2}{*}{$0.8 \mathrm{AU}$} & June-August & 801 & $760-833$ & 5.70 & 65.86 \\
\hline & September-November & 899 & $893-910$ & 5.30 & 70.92 \\
\hline Improved natural pasture & September-November & 2244 & $2145-2312$ & 11.99 & 49.90 \\
\hline $0.7 \mathrm{AU}$ & November-January & 2449 & $2295-2692$ & 6.50 & 74.47 \\
\hline
\end{tabular}


Data were submitted to analysis of variance, and means were compared by the t-test at $5 \%$ significance levels, using SAS statistical package (Statistical Analyses System, version 6). The following model was applied:

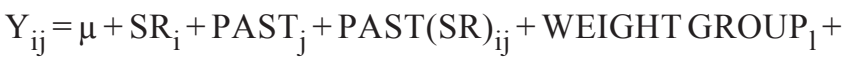
eijl; $\mathrm{i}=1.2 ; \mathrm{j}=1.2, \mathrm{l}=1.2 .3$, where $\mathrm{Y}_{\mathrm{ijl}}=\mathrm{IW}$ (initial weight), FW (final weight), IBCS (initial body condition score), FBCS (final body condition score), DAV (daily average weight variation) of the $\mathrm{k}$-th heifer, belonging to the $\mathrm{i}$-th stocking rate (SR), to the $\mathrm{j}$-th Pasture (PAST) and to the 1-th weight group (WEIGHT GROUP); $\mu=$ general mean; $\mathrm{SR}_{\mathrm{i}}=$ effect of the $\mathrm{i}$-th stocking rate; $\mathrm{PAST}_{\mathrm{j}}=$ effect of pasture $\mathrm{j}$; WEIGHT GROUP W $_{1}$ effect of weight group $\mathrm{j}$; eijl $=$ effect of the random error associated to each $Y_{i j 1}$ observation.

Continuous parameters with normal distribution were analyzed considering an unequal number of replicates. The effect of feeding management on pregnancy rate was analyzed by the Chi-Square test at $5 \%$ probability level (Steel \& Torrie, 1989).

\section{Results and Discussion}

Heifers submitted to stocking rates of 0.6 and $0.8 \mathrm{AU} / \mathrm{ha}$, with average forage allowances between June and August of 1183 and $801 \mathrm{~kg} \mathrm{DM} /$ ha, respectively, suffered significant weight loss, which considerably affected their body weight as measured on Sept $1^{\text {st }}, 2008$ (Tables 1 and 2). In the beginning of the experiments, heifers managed at $0.6 \mathrm{AU} / \mathrm{ha}$ had an allowance of $4.07 \mathrm{~kg}$ of DM/100-kg body weight (BW), whereas the stocking rate of $0.8 \mathrm{AU} /$ ha provided an allowance of only $2.52-\mathrm{kg} \mathrm{DM} / 100-\mathrm{kg}$ BW. On Aug $1^{\text {st }}$, 2008 , forage allowances were 4.55 and $2.80-\mathrm{kg} \mathrm{DM} / 100-\mathrm{kg}$ $\mathrm{BW}$, which were virtually the same as 60 days before due to weight loss: on Sept $1^{\text {st }}$, heifers accumulated BW losses of -12.7 and $-32.7 \mathrm{~kg}$, grazing at stocking rates of 0.6 and 0.8 $\mathrm{AU} / \mathrm{ha}$, respectively. On average, during this period, heifers grazing at $0.6 \mathrm{AU} /$ ha were supplied $4.32-\mathrm{kg} \mathrm{DM} / 100-\mathrm{kg} \mathrm{BW}$, whereas those grazing at $0.8 \mathrm{AU} / \mathrm{ha}$ received $2.62 \mathrm{~kg} \mathrm{DM} / 100 \mathrm{~kg}$ $\mathrm{BW}$. These allowances were low, particularly for the season, and, associated to the forage quality (Table 1), they determined the observed BW losses. High stocking rates resulted in low forage allowance and pasture height (Neves et al., 2009).

When submitting heifers of the same age to $4 \%$ forage allowance-higher than those used in the present experiment - during the entire year, Neves et al. (2009) found considerable daily weight gain and body condition score losses. This information is important for the animal class under study, as high weight loss in heifers may result in failure at first breeding (Lobato, 2003), and therefore, compromise a relevant step of the calf production macroprocess (Rosado Júnior \& Lobato, 2009).

Forage allowances lower than $8-\mathrm{kg}$ DM/100-kg BW maintain average pasture height below $6.0 \mathrm{~cm}$, which is the minimum height promoting efficient grazing by cattle (Neves et al., 2009). With 8\% DM, pastures are capable of maintaining their regrowth and structure, thereby providing adequate allowance, height and quality (Maraschin, 2001).

The biggest losses occurred during the worst winter period, between Jul $1^{\text {st }}$ and Aug $1^{\text {st }}$, with -0.5 and $-0.7 \mathrm{~kg} /$ day at stocking rates of 0.6 and $0.8 \mathrm{AU} / \mathrm{ha}$, respectively. During this period, weather and plant structure, associated to soil and relief characteristics (Neves et al., 2009), as well as pasture allowance and quality, may have caused considerable losses.

Although the paddocks had been previously closed for 40 days, DM accumulation was insufficient to prevent BW losses during that period. Scholl et al. (1976) closed paddocks for 60 days, and obtained a pasture allowance of more than $30-\mathrm{kg} \mathrm{DM} / 100 \mathrm{~kg}$, which resulted in $4.5-\mathrm{kg} \mathrm{BW}$ gain during the winter, with higher gains during the first 28 days.

Body weight loss when cattle are grazing natural pastures during periods of low pasture allowance and quality is normal, mainly due to low allowance (Pilau \& Lobato, 2006; Vaz \& Lobato, 2010a). Menegaz et al. (2008) obtained $0.189-\mathrm{kg} /$ day weight gain during the period of June 11 to July 08, but with an initial allowance of 2520-kg $\mathrm{DM} / \mathrm{ha}$. During the period from June 11 to Sept 10, average weight gain was $0.261 \mathrm{~kg} /$ day, but with an average allowance of $1817 \mathrm{~kg} \mathrm{DM} / \mathrm{ha}$. Under the conditions of the study of Menegaz et al. (2008), monthly DM/ha allowances of 2520, 2062, 1470 and $1216 \mathrm{~kg} \mathrm{DM} /$ ha were obtained.

During the period from Aug $1^{\text {st }}$ to Sept $1^{\text {st }}, 2008$, increasing sunlight and temperature increased natural pasture quality, promoting weight gains, according to

Table 2 - Average body weight ( $\mathrm{kg}$ ) of heifers grazing natural pastures at stocking rates of 0.6 or $0.8 \mathrm{AU} /$ ha between June $1^{\text {st }}$ and September $1^{\text {st }}$

\begin{tabular}{lcc}
\hline & \multicolumn{2}{c}{ Stocking rate } \\
\cline { 2 - 3 } Weighing days & $0.6 \mathrm{AU}$ & $0.8 \mathrm{AU}$ \\
\hline June $1^{\text {st }}, 2008$ & $262.8 \pm 1.38 \mathrm{a}$ & $261.8 \pm 1.39 \mathrm{a}$ \\
Jul $1^{\text {st }}, 2008$ & $249.8 \pm 1.47 \mathrm{a}$ & $246.3 \pm 1.45 \mathrm{a}$ \\
Aug $1^{\text {st }}, 2008$ & $234.8 \pm 1.31 \mathrm{a}$ & $224.1 \pm 1.29 \mathrm{~b}$ \\
Sept $1^{\text {st }}, 2008$ & $250.1 \pm 1.50 \mathrm{a}$ & $229.1 \pm 1.49 \mathrm{~b}$ \\
Total body weight variation & $-12.7 \pm 1.00 \mathrm{a}$ & $-32.7 \pm 1.01 \mathrm{~b}$ \\
Average daily weight variation & $-0.138 \pm 0.011 \mathrm{a}$ & $-0.356 \pm 0.011 \mathrm{~b}$ \\
\hline a,b-Means in the same row followed by different letters are different by t-test \\
$(\mathrm{P}<0.05)$.
\end{tabular}


stocking rate, of $0.533 \mathrm{~kg}$ and $0.170-\mathrm{kg} / \mathrm{day}$ with 0.6 and $0.8 \mathrm{AU} / \mathrm{ha}$, respectively. Menegaz et al. (2008), between Aug 10/08 and Sept 10, determined weight gains of $0.435 \mathrm{~kg} /$ day with $0.6 \mathrm{AU} / \mathrm{ha}$ and $9.36-\mathrm{kg} \mathrm{DM} / 100 \mathrm{~kg} \mathrm{BW}$ allowance.

The results found in the literature relative to animal performance in natural pastures during autumn and winter are very contradictory, as influenced by climate (rainfall and temperature) and diversity of the flora of the studied region (Menegaz et al., 2008; Neves et al., 2009). Menegaz et al. (2008) obtained in natural pastures average weight gains of $0.261 \mathrm{~kg}$, but at a lower stocking rate $(0.6 \mathrm{AU} / \mathrm{ha}$ and 1345-kg DM/ha), which supplied higher pasture allowance as that obtained in the present study. Animal performance depends on pasture allowance, which is adjusted by stocking rate (Moojen \& Maraschin, 2002; Neves et al., 2009).

On September $1^{\text {st }}, 2008,82$ heifers grazing at 0.6 and $0.8 \mathrm{AU} / \mathrm{h}$ a were maintained in the same paddocks, whereas 80 were transferred to improved natural pastures (I) at stocking rates of 0.6 UAI and 0.8 UAI (Table 3).

Regardless of the stocking rate applied until Nov $15^{\text {th }}$, 2008, the heifers at improved natural pastures gained significantly more weight than those maintained on natural pastures $(0.869$ vs. $0.421 \mathrm{~kg} /$ day for heifers at $0.6 \mathrm{AU}$ and $0.747 \mathrm{vs} .0 .454 \mathrm{~kg} /$ day for heifers at $0.8 \mathrm{AU} ; \mathrm{P}<0.05$ ).

The higher weight gain obtained by heifers, regardless of the previous feeding management, is explained by the improvement in the quality of natural pastures in the spring and by the higher quality of the improved natural pastures (Table 1). The higher efficiency and higher weight gain observed are due to the higher consumption of metabolizable energy, which was higher than maintenance requirements, allowing the animal to direct the ingested nutrients to tissue accretion, increasing its efficiency to gain weight (Poppi \& McLennan, 1995). Pilau \& Lobato (2006) also observed weight recovery in cattle from different herds after a period of feed restriction when grazing natural pastures during the winter, and attributed this recovery to the interaction between pasture quality, compensatory gain, and genetic potential.

Heifers grazing on improved natural pastures between Sept $1^{\text {st }}$ and Nov 15, 2008 gained s106.4 and 64.5\% more weight was compared with those grazing on natural pastures at $0.6-\mathrm{AU}$ and 0.8 -AU stocking rates. This suggests that there was compensatory gain during this period, with heifers submitted to more stringent feed restriction in the previous period obtaining higher weight gain when the available feed was sufficient to demonstrate this compensation. After feed restriction, animals are able to recover their body weight and gain weight under adequate feed allowance (Di Marco, 1998). According to Ryan (1990), ruminants maintained under feed restriction tend to compensate their average daily gain when restriction ends, and the intensity of gain weight is influenced by feed quality, feed restriction period, and animal age.

Regardles of the stocking rates used in heifer management, compensatory gain was observed in the subsequent periods, as previously observed by Simeone \& Lobato, (1998) and Restle et al. (1999), albeit not significant (Almeida \& Lobato, 2004).

The better performance demonstrated by the higher weight gain before the breeding season is critical for the reproductive performance of heifers, as the higher nutrient supply triggers the secretion and release of reproductive hormones (Schillo, 1992). With higher protein supply, and particularly higher energy supply, to heifers, LH pulses are more intense and occur at shorter intervals (Kinder et al., 1994). Neves et al. (2009), working with excessive stocking rates, observed lower cycling and lower reproductive tract scores.

Average body weights in the beginning and end of the breeding season were higher $(\mathrm{P}<0.05)$ for heifers grazing on improved natural pastures until Nov 15, 2008 as compared with those grazing exclusively on natural pastures (Table 4).

The average body weights of 261,314, 264 and $306 \mathrm{~kg}$ obtained at the beginning of the breeding season for $0.6 \mathrm{AU}$, $0.6 \mathrm{AUI}, 0.8 \mathrm{AU}$ and $0.8 \mathrm{AUI}$, respectively, represent 52, 63, 53 and $61 \%$ of the mature weight of the studied herd, whose cows sold for slaughter at a body condition score of 4.5 - 5.0 presented 500-kg average weight. Therefore, the percentage of mature weight of 24-25-month-old heifers obtained with the use of improved natural pastures in the present study

Table 3 - Average weight and weight variation according to stocking rate of heifers grazing on natural pastures or improved natural pastures during the period of Sept $1^{\text {st }}$ to Nov 15,2008

\begin{tabular}{|c|c|c|c|c|}
\hline \multirow[b]{2}{*}{ Weight measurement } & \multicolumn{2}{|c|}{$0.6 \mathrm{AU}$} & \multicolumn{2}{|c|}{$0.8 \mathrm{AU}$} \\
\hline & Natural pasture & Improved pasture & Natural pasture & Improved pasture \\
\hline Sept $1^{\text {st }}, 2008, \mathrm{~kg}$ & $229 \pm 1.3 b$ & $248 \pm 2.1 \mathrm{a}$ & $230 \pm 1.3 b$ & $250 \pm 2.2 \mathrm{a}$ \\
\hline Weight gain, $\mathrm{kg}$ & $32 \pm 1.4 b$ & $66 \pm 2.0 \mathrm{a}$ & $34 \pm 1.4 b$ & $56 \pm 2.0 \mathrm{a}$ \\
\hline Average daily gain, $\mathrm{kg}$ & $0.421 \pm 0.018 \mathrm{~b}$ & $0.869 \pm 0.026 \mathrm{a}$ & $0.454 \pm 0.018 b$ & $0.747 \pm 0.017 \mathrm{a}$ \\
\hline
\end{tabular}

$\mathrm{a}, \mathrm{b}$ - Means in the same row followed by different letters are different, within stocking rate, by t-test $(\mathrm{P}<0.05)$ 
is slightly higher than the required weights mentioned in the literature, except for Freetly (1999), who considers that heifers are well developed when reaching $70 \%$ of their mature weight at two years of age. According to the NRC (1996), Bos taurus heifers must weigh at least $60 \%$ of their mature weight to be able to reach puberty and to conceive. Rovira (1996) mentions that 280 to $300-\mathrm{kg}$ BW in British breeds and their crosses are sufficient to achieve at least $85 \%$ pregnancy during the first six weeks of the breeding season.

During the breeding season, all heifers were maintained as a single group on natural pastures at a stocking rate of $315-\mathrm{kg} \mathrm{BW} / \mathrm{ha}(0.70 \mathrm{AU} / \mathrm{ha})$. During this period, their daily weight gain was lower than that obtained by the heifers grazing on improved natural pastures between Sept $1^{\text {st }}$ and Nov 15, 2008. The ruminal flora adjustment required when changing for poorer nutritional regimes, according to Van Soest (1994), determines lower weight gain or even weight loss when the new feeding regime starts. Cattle changed to low quality feeding conditions immediately after a period when their performance was close to their optimal potential present weigh gain reduction (Allden \& Morley, 1981).

Rocha et al. (2004), evaluating the development of beef heifers grazing on lopsided oats and ryegrass, with or without energy supplementation, also found low weight gain and weight loss when heifers were subsequently placed on natural pasture in the beginning of spring. According to Ferrell (1982) and Van Soest (1994), the adaptation of the ruminal microbial flora is one of the possible causes of the worse performance of cattle removed from improved pastures and submitted to new feeding management as they require some time to adjust to the new diet.

The FDN and crude protein values determined in the natural pasture used during the breeding season (Table 1) determined the low weight gain of the heifers during this period. According to Van Soest (1994), high FDN levels limit forage intake, as they are associated to rumination, passage rate, and feed intake.

The heifer average weight gains obtained in the present study are higher than those observed by Rocha et al. (2004), who, when evaluating heifers exposed to breeding at 13-15 months of age after grazing on cultivated winter/spring pastures, observed weigh losses of $-0.185 \mathrm{~kg} / \mathrm{heifer} /$ day on natural pastures. In order to prevent losses and gradual adjustment to the new forage matrix, Pilau \& Lobato (2009) worked with heifers at 13-15 months of age to be bred before leaving cultivated pastures and at the beginning of grazing on natural pastures, supplemented or not with corn grain, and, for the period, obtained weight gains of 0.800 vs. $0.658 \mathrm{~kg} /$ day $(\mathrm{P}<0.05)$, respectively. The weight gains determined in the present study are lower than the $0.384 \mathrm{~kg} / \mathrm{day}$ reported by Vaz \& Lobato (2010b), who worked with heifers bred at 13-15 months of age that were submitted to early weaning at 77 days or at the conventional age of 147 days.

Literature reports very variable body weight performances during the breeding season due to the conditions under which the studies were carried out. However, several authors agree that, regardless of weight gain during the breeding season, body weight in the beginning of the breeding season is critical for obtaining adequate reproductive response that is required in intensive beef cattle production systems (Rovira, 1996; Rocha \& Lobato, 2002; Pilau \& Lobato, 2008; Vaz \& Lobato 2010b).

The analysis of variance of body condition score showed differences between feeding management practices $(\mathrm{P}<0.05)$, with heifers previously grazing on improved natural pastures obtaining higher scores. Body condition score is a good indicator of subcutaneous fat deposition, which determines the early manifestation of estrus, even before the breeding season and as well as reproductive performance itself(Lemenager et al., 1980).

Average body condition scores at the beginning and end of the breeding season of 3.2 and $3.1(\mathrm{P}>0.05)$ obtained

Table 4 - Development and reproductive performance of heifers according to stocking rates on natural pastures and improved natural pastures before the breeding season

\begin{tabular}{|c|c|c|c|c|}
\hline \multirow[b]{2}{*}{ Body weight and body condition score } & \multicolumn{2}{|c|}{$0.6 \mathrm{AU}$} & \multicolumn{2}{|c|}{$0.8 \mathrm{AU}$} \\
\hline & Natural pasture & Improved natural pasture & Natural pasture & Improved natural pasture \\
\hline Weight beginning of the breeding season, $\mathrm{kg}$ & $261 \pm 2.2 b$ & $314 \pm 3.1 \mathrm{a}$ & $264 \pm 2.2 b$ & $306 \pm 3.1 \mathrm{a}$ \\
\hline Weight end of the breeding season, $\mathrm{kg}$ & $294 \pm 2.0 b$ & $320 \pm 3.0 \mathrm{a}$ & $278 \pm 2.0 \mathrm{~b}$ & $316 \pm 3.0 \mathrm{a}$ \\
\hline Average daily gain, $\mathrm{kg}$ & $0.211 \pm 0.024 \mathrm{a}$ & $0.105 \pm 0.035 b$ & $0.237 \pm 0.025 \mathrm{a}$ & $0.162 \pm 0.036 \mathrm{a}$ \\
\hline Body condition score beginning of the breeding season & $2.8 \pm 0.03 b$ & $3.2 \pm 0.04 \mathrm{a}$ & $2.5 \pm 0.03 b$ & $3.1 \pm 0.05 \mathrm{a}$ \\
\hline Body condition score end of the breeding season & $2.8 \pm 0.03 b$ & $3.3 \pm 0.05 \mathrm{a}$ & $2.6 \pm 0.03 b$ & $3.2 \pm 0.05 \mathrm{a}$ \\
\hline Pregnancy, \% & $51.9 \mathrm{~B}$ & $87.5 \mathrm{~A}$ & 28.4B & $80.0 \mathrm{~A}$ \\
\hline Beginning breeding season conception interval, days & $33.1 \mathrm{a}$ & $28.3 \mathrm{a}$ & $42.6 \mathrm{~b}$ & $34.5 \mathrm{a}$ \\
\hline
\end{tabular}

$\mathrm{a}, \mathrm{b}-$ Means in the same row followed by different letters are different, within stocking rate, by the $\mathrm{t}$-test $(\mathrm{P}<0.05)$.

$\mathrm{A}, \mathrm{B}-$ Means in the same row followed by different letters are different, within pasture allowance, by the Chi-Square test $(\mathrm{P}<0.05)$ 
with treatments of $0.6 \mathrm{AUI}$ and $0.8 \mathrm{AUI}$ were higher than the body condition scores of 2.8 and 2.55 of heifers managed at stocking rates of $0.6 \mathrm{AU}$ and $0.8 \mathrm{AU}$ on natural pastures, respectively. Literature shows that body condition scores higher than 3.0 are sufficient for obtaining good reproductive results in two-year-old heifers (Menegaz et al., 2008). In the present study, the body condition scores of heifers grazing on natural pastures were limiting for good reproductive results. Low weight and body condition development of heifers negatively affect herd reproductive performance as they delay age at conception, resulting in lower productivity in calving-to-finishing systems (Pötter et al., 2000; Beretta et al., 2001; Vieira et al., 2006).

In spite of the previous feeding management practice, body condition score did not evolve during the breeding season due to the low weight gain during this period. Increasing body condition reflects the sufficient energy to supply animal requirements, influencing weight gain and accelerating fat deposition. There is a strong relationship between body weight and body condition score in heifers due to the significant need for muscle tissue accretion, as they are still growing (Pilau \& Lobato, 2006; Vaz \& Lobato 2010a).

Regardless of stocking rate until Sept $1^{\text {st }}$, heifers that grazed on improved natural pastures presented significantly higher pregnancy rates (Table 4), as a result of achieving the minimum body weights and body condition scores previously discussed in this paper. These results are consistent with other studies that, in spite of the breed and heifer age at pregnancy (24-26 or 14-15 months), also stress the need for achieving adequate minimum body weight and body condition score to obtain significant pregnancy rates (Semmelmann et al., 2001; Rocha \& Lobato, 2002; Pilau \& Lobato, 2006; Menegaz et al., 2008; Vaz \& Lobato, 2010b).

Heifer pregnancy rate was influenced by the initial stocking rates to which heifers were submitted. Those grazing at $0.6 \mathrm{AU}$ presented $69.7 \%$ pregnancy rate, whereas those at $0.8 \mathrm{AU}$ presented $54.2 \%$. These results demonstrate the importance of stocking rate and resulting pasture allowance, even when grazing only natural pastures, on body weight and body condition score in the beginning and end of the breeding season, and consequent heifer reproductive performance, as previously reported by Menegaz et al. (2008) and Vaz \& Lobato (2010b).

Heifers grazing 60 days before the breeding season on improved natural pastures conceived, on average, 31.3 days earlier $(\mathrm{P}<0.05)$; however, their conception time was not different from those grazing on natural pastures at low stocking rate (33.3 days), which presented the highest body weight and body condition score between heifers grazing on natural pastures. Menegaz et al. (2008) observed the same trend in heifers with higher weight gain and body condition score in the beginning of the breeding season, obtaining average conception rates of 30.6, 36.5 and 39.4 days for heifers previously grazing on improved natural pastures, natural pastures and natural pastures with supplementation, respectively.

The better forage allowance and quality determined the difference in the number of days required to conceive between heifers submitted to different forage systems before the breeding season. Byerley et al. (1987) emphasize that estrus fertility increases up to the third estrus. Early conception in the breeding season has positive influence on the reproductive performance of first-calf cows, as they allow a higher number of days between calving and the end of the second breeding season (Osoro, 1986).

There were differences in weight loss during autumn and winter, and, after Sept $1^{\text {st }}$, heifers grazing on natural pastures devloped slower and those grazing on improved natural pastures hd better response (Figure 1).

As there was no interaction between stocking rate and pasture type (natural or natural associated with the use of improved natural pastures) on heifer initial weight, this effect is discussed separately.

When heifers were classified in the beginning of the study in three weight groups (Light, Medium and Heavy, with 241,259 and $286 \mathrm{~kg}$ average body weight, respectively), it was observed that, during the period of autumn-winter, heavier heifers lost more of it. Light, Medium and Heavy heifers lost $0.192,0.242$ and $0.307 \mathrm{~kg} /$ day $(\mathrm{P}<0.05)$, respectively (Table 5) until Sept $1^{\text {st }}, 2008$. The weight

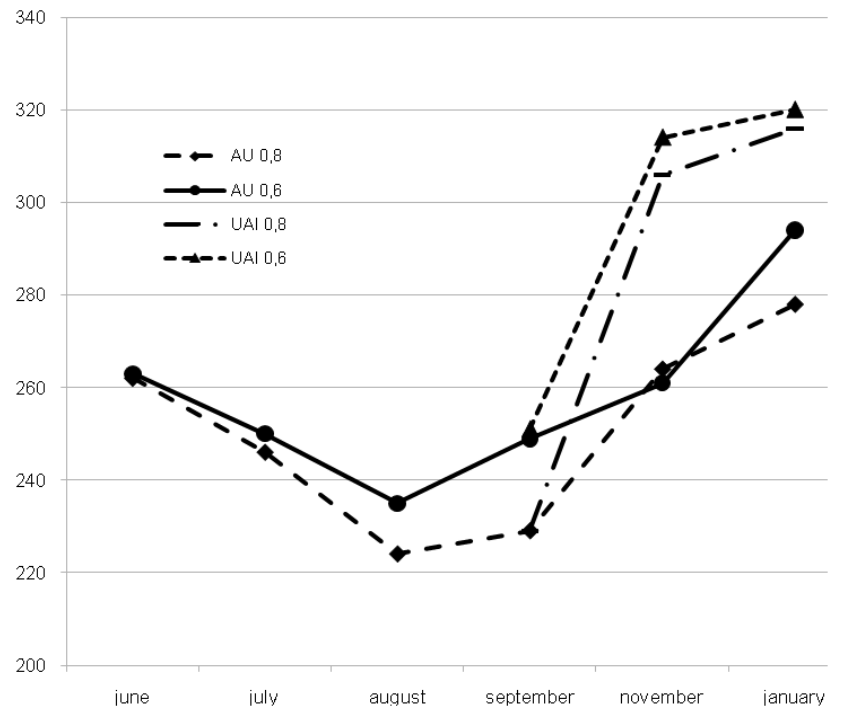

Figure 1 - Body weight evolution of heifers between June $1^{\text {st }}$ and the end of the breeding season according to feeding management practice. 
differences measured in the beginning of the study were maintained until Sept $1^{\text {st }}$, but with increasing weight losses $(\mathrm{P}<0.05)$ as heifer body weight increased $(-0.192 ;-0.242$ and $-0.307 \mathrm{~kg} /$ day; Table 5). The higher weight loss in the heavier heifers during periods of nutritional deficiencies is due to their higher requirements and higher feed intake (Di Marco, 1998), which require animals to use their body reserved to supply maintenance requirements.

Menegaz et al. (2008), also studying the effect of feeding management practices on the reproduction of two-year-old heifers classified in three weight groups, also observed the same trend towards maintenance of the initial weight groups. Those authors worked with lower initial body weights, but observed, instead of weight loss, average daily gains of $0.600,0.612$ and $0.634 \mathrm{~kg} /$ day $(\mathrm{P}>0.05)$ in Light, Medium and Heavy heifers, respectively, during the same season.

The weight groups remained different in the beginning and end of the breeding season $(\mathrm{P}<0.05)$, indicating that, regardless of initial body weight, heifers presented similar weight gain during the breeding season.

The results show that the forage systems used in the present study maintained the body weight differences from the beginning of the study until the end of the breeding season between weight groups. However, body condition score differences were obtained both in the beginning and the end of the breeding season. Heavy heifers presented significantly higher body condition score, which allows us to assume that that group has better genetic potential for weight gain and precocity. Nevertheless, heifers with larger mature size and heavier mature weight tend to deposit fat later, particularly when feed is limiting in quantity and quality (Di Marco, 1998). Pereira Neto \& Lobato (1998) and Menegaz et al. (2008) found better body condition score in lighter animals.
There was no difference in average conception date between weight groups, with Light, Medium and Heavy heifers conceiving on days 31.3,33.3 and 32.4, respectively. Menegaz et al. (2008) observed that heavy heifers presented lower breeding-conception interval (29.86 days) $(\mathrm{P}<0.05)$ as compared with medium and light heifers (36.80 and 39.83 days, respectively), which were not different.

The pregnancy rate of heavy heifers $(71.5 \%)$ was higher $(\mathrm{P}<0.05)$ than those of the medium (61.2\%) and light (54.9\%) heifers, which were not different. Heavy heifer pregnancy rate was $16.6 \%$ higher in heavy heifers relative to the light heifers. These results, according to literature, show the beneficial effects of the association of body weight to a higher percentage of mature weight and the resulting conception rate of heifers: the heavier or the higher the development of the heifers, the higher their conception rate. At the beginning of the breeding season, light, medium and heavy heifers presented $55 \%, 58 \%$ and $62 \%$ of the $500-\mathrm{kg}$ mature weight of the herd, and at the end of that season, $57 \%, 60 \%$ and $64 \%$, respectively. Therefore, only the heavy heifers had more than $60 \%$ of the mature weight in the beginning and the end of the breeding season, as recommended by the NRC (1996) for the beginning of breeding. The influence of the higher body weight in the beginning and end of the breeding season was also observed in heifers bred at 24-26 months of age (Pereira Neto \& Lobato, 1998; Menegaz et al., 2008) and at 14-15 months of age (Rocha \& Lobato, 2002; Vaz \& Lobato, 2010b).

In intensive beef cattle production systems, where there are no forage limitations, most heifers are heavy, with high pregnancy rates. However, if this continues throughout the years, heifer frame and weight may increase due to selection of larger animals, which may result in late sexual maturity and higher maintenance requirements of the breeding herd caused by the larger mature size (Jenkins

Table 5 - Average development and reproductive performance parameters of beef heifers with different body weights

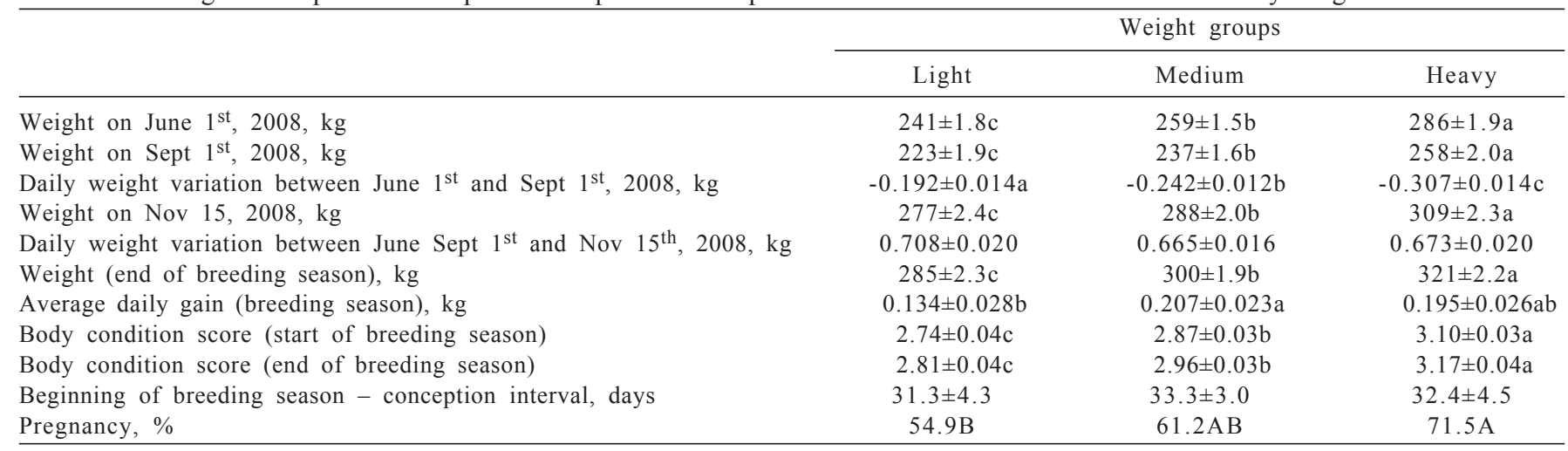

a,b,c - Means in the same row followed by different letters are different by the t-test $(\mathrm{P}<0.05)$.

A,B - Means in the same row followed by different letters are different by the Chi-Square test $(\mathrm{P}<0.05)$. 
\& Willians, 1994; Cundiffet al., 1998), affecting fist-calf cow reproduction, as observed by Olson (1994) and recently by Lobato et al. (2010) and Tanure et al. (2011).

Although all heifers were born in the same season of 90 days in 2006, weight groups may have been confused with age in days, as the precise date of birth of the heifers was no available. Therefore, heavier heifers could have been the older ones. This is important in intensive production systems (Pötter et al., 1998; Beretta et al., 2002), since the pregnant heifers are usually the heaviest, the eldest, and present the highest body condition scores and weight gains from birth until the end of the breeding season (Rocha \& Lobato, 2002; Vieira et al., 2006; Vaz \& Lobato, 2010b). In calving-to-finish systems, heifers that conceive earlier in their first breeding season are usually the first-calf cows with the highest pregnancy rates (Vieira et al., 2006; Vazetal., 2010).

\section{Conclusions}

Natural pastures need to be closed for longer and grazed at lower stocking rates to supply forage allowances that prevent heifer weight loss during the fall and winter. Grazing on improved natural pastures results in adequate body weight and body conditions that promote good reproductive indexes and earlier conception. Heavier heifers present higher pregnancy rates. In essentially grazing systems, particularly in calving-to-finish systems, where all animal classes have to go through steps along the seasons to achieve successful reproduction, the continuous followup of animal development is critical. Supplying adequate feeding and development to the different herd classes is essential for the achievement of high productive and economic outcomes, which determine the income of farmers.

\section{References}

ALLDEN, W.G.; MORLEY, F.H.W. Energy and protein supplementation for grazing livestock. Grazing animals. Amsterdam: Elsevier, 1981. 411p.

ALMEIDA, L.S.P.; LOBATO, J.F.P. Efeito da idade de desmame e suplementação no desenvolvimento de novilhas de corte. Revista Brasileira de Zootecnia, v.33, n.6, p.2086-2094, 2004 (supl.2).

ASSOCIATION OF OFFICIAL ANALYTICAL CHEMITS - AOAC. Official methods of analysis. 14.ed. Washington, D.C., 1984. $1141 \mathrm{p}$.

BerettA, V.; LOBATO, J.F.P.; MIELitZ NETO, C.G.A. Produtividade e eficiência biológica de sistemas Pecuários de cria diferindo na idade das novilhas ao primeiro parto e na taxa de natalidade do rebanho no Rio Grande de Sul. Revista Brasileira de Zootecnia, v.30, n.4, p.1278-1286, 2001.

BERETTA, V.; LOBATO, J.F.P.; MIELITZ NETO, C.G.A. Produtividade e eficiência biológica de sistemas de produção de gado de corte de ciclo completo no Rio Grande do Sul. Revista Brasileira de Zootecnia, v.31, n.2, p.991-1001, 2002 (supl.) BYERLEY, D.J.; STAIGMILLER, R.B.; BERARDINELLI, J.G. et al Pregnancy rates of beef heifers bred either on puberal or third estrus. Journal of Animal Science, v.65, n.5, p.645-650, 1987.

CUNDIFF, L.V.; DIKEMAN, M.E.; KOCH, R.M. et al. Beeding for lean beef (germ plasm evaluation program). Beef Research Progress Report, n.3, p.5-8, 1998.

DI MARCO, O.N. Crecimiento de vacunos para carne. 2.ed. Mar Del Prata, República Argentina, 1998. 246p.

FERRELL, C.L. Effects of postweanning rate of gain on onset of puberty and productive performance of heifers of different breeds. Journal of Animal Science, v.55, n.6, p.1272-1283, 1982.

FREETLY, H.C. The replacement heifer and the primiparous cow. In: REUNIÃO ANNUAL DA SOCIEDADE BRASILEIRA DE ZOOTECNIA, 36., 1999, Porto Alegre. Anais... Porto Alegre: SBZ, 1999. p.241-249.

HAYDOCK, K.P.; SHAW, N.H. The comparative yield method for stimating dry matter yield of pasture. Australian Journal of Experimental Agriculture and Animal Husbandry, v. 15 , n.76, p.663-670, 1975 .

KINDER, J.E.; ROBERSON, M.S.; WOLFE, M.W. et al Management factors affecting puberty in the heifer. In: FIELDS, M.J.; SAND, R.S. (Eds.) Factors affecting calf crop. Boca Raton: CRC Press, 1994. p.69-89.

JENKINS, T.G.; WILLIANS, C.B. Performance of different biological types with variable levels of feed availability. In: THE BEEF VANGUARD 1994 INTERNATIONAL CONGRESS, 1994, Buenos Aires. Proceedings... Buenos Aires, 1994. p.29-39.

LEMENAGER, R.P.; SMITH, W.H.; MARTIN, T.G. et al. Effects of winter and summer energy levels on heifers growth and reproductive performance. Journal of Animal Science, v.51, n.4, p.837-842, 1980.

LOBATO, J.F.P. A "vaca ideal" e o seu manejo em sistemas de produção de ciclo curto. In: SIMPÓSIO DA CARNE BOVINA DA PRODUÇÃO AO MERCADO CONSUMIDOR, 1., 2003, São Borja. Anais... Porto Alegre: UFRGS, 2003. p.09-43.

LOBATO, J.F.P.; MENEGAZ, A.L.; PEREIRA, A.C.G. Pre and postcalving forage systems and reproductive performance of primiparous cows. Revista Brasileira de Zootecnia, v.39, n.9, p.2081-2090, 2010.

LOWMAN, B.G.; SCOTT, N.; SOMERVILLE, S. Condition scoring beef cattle. Edinburgh: East of Scotland College of Agriculture, 1973. 8p.

MARASCHIN, G.E. Production potential of South American grasslands. In: INTERNATIONAL GRASSLAND CONGRESS 19., 2001, Piracicaba. Proceedings... Piracicaba: Escola Superior de Agricultura Luiz de Queiroz, 2001. p.5-18.

MENEGAZ, A.L.; LOBATO, J.F.P.; PEREIRA, A.C.G. Influência do manejo alimentar no ganho de peso e no desempenho reprodutivo de novilhas de corte. Revista Brasileira de Zootecnia, v.37, n.10, p.1844-1852, 2008.

MOOJEN, E.L.; MARASCHIN, G.E. Potencial produtivo de uma pastagem nativa do Rio Grande do Sul submetida a níveis de oferta de forragem. Ciência Rural, v.32, n.1, p.127-132, 2002.

NATIONAL RESEARCH COUNCIL - NRC. Nutrient requeriments of beef cattle. Washington D.C.: National Academy Press, 1996. 244p.

NEVES, F.P.; CARVALHO, P.C.F.; NABINGER,C. et al. Estratégias de manejo da oferta de forragem para recria de novilhas em pastagem natural. Revista Brasileira de Zootecnia. v.38, n. 8, p. $1532-1542,2009$

OLSON, T.A. The effect of cow size on reproduction. In: FIELDS, M.J.; SANDS, R.S. (Eds.) Factors affecting calf crop. London: CRC Press, 1994. p.243-249.

OSORO, K.O. Effecto de las principales variables de manejo sobre los parametros reproductivos en las vacas de cria. Producción y Sanidade Animales, v.1, n.7, p.87-111, 1986. 
PEREIRA NETO, O.A.; LOBATO, J.F.P. Efeitos da ordem de utilização de pastagens nativas melhoras no desempenho e comportamento reprodutivo de novilhas de corte. Revista Brasileira de Zootecnia, v.27, n.1, p.60-65, 1998.

PEREIRA NETO, O.; LOBATO, J.F.P.; SIMEONE, A. Sistema de pastejo rotativo ponta e rapador para bezerras de corte. 1. Desempenho corporal. Revista Brasileira de Zootecnia, v.28, n.1, p.137-142, 1999.

PILAU, A.; LOBATO, J.F.P. Recria de bezerras com suplementação no outono e pastagem cultivada de inverno. Revista Brasileira de Zootecnia, v.35, n.6, p.2388-2396, 2006.

PILAU, A.; LOBATO, J.F.P. Manejo de novilhas prenhes aos 13/15 meses de idade em sistemas a pasto. Revista Brasileira de Zootecnia, v.37, n.7, p.1271-1279, 2008.

PILAU, A.; LOBATO, J.F.P. Suplementação energética préacasalamento aos 13/15 meses de idade para novilhas de corte: desenvolvimento e desempenho reprodutivo. Revista Brasileira de Zootecnia, v.38, n.12, p.2482-2489, 2009.

POPPI, D.P.; McLENANN, S.R. Protein and energy utilization by ruminants at pasture. Journal of Animal Science, v.73, n.1, p.278-290, 1995.

PÖTTER, L.; LOBATO, J.F.P.; MIELITZ NETO, C.G.A. Análises econômicas de modelos de produção com novilhas de corte primíparas aos dois, três ou quatro anos de idade. Revista Brasileira de Zootecnia, v.29, n.3, p.861-870, 2000.

PÖTTER, L.; LOBATO, J.F.P.; MIELITZ NETO, C.G.A. Produtividade de um modelo de produção para novilhas de corte primíparas aos dois, três e quatro anos de idade. Revista Brasileira de Zootecnia, v.27, n.3, p.613-619, 1998.

RESTLE, J.; BRONDANI, I.L.; FLORES, J.L.C. et al. Desempenho de genótipos de novilhos para abate aos quatorze meses, gerados por fêmeas de dois anos. Pesquisa Agropecuária Brasileira, v.34, n.11, p.2123-2128, 1999.

ROCHA, M.G.; LOBATO, J.F.P. Avaliação do desempenho reprodutivo de novilhas de corte primíparas aos dois anos de idade. Revista Brasileira de Zootecnia, v.31, n.3, p.13881395, 2002 (supl.).

ROCHA, M.G.; PILAU, A.; SANTOS, D.T. et al. Desenvolvimento de bezerras de corte submetidas a diferentes sistemas de alimentares. Revista Brasileira de Zootecnia, v.33, n.6, p.2123-2131, 2004 (supl 2).

ROVIRA, J.M. Manejo nutritivo de los rodeos de cria em pastoreo. Montivideo: Hemisfério Sur, 1996. 288p.

ROSADO JÚNIOR, A.G.; LOBATO, J.F.P. application of a model of management by macroprocesses to a beef cattle enterprise: a case study. Revista Brasileira de Zootecnia, v.38, n.11, p.2280-2288, 2009
ROSADO JÚNIOR, A.G.; LOBATO, J.F.P. Implementation of a performance indicators system in a beef cattle company. Revista Brasileira de Zootecnia, v.39, n.6, p.1372-1380, 2010.

RYAN, W.J. Compensatory growth in cattle and sheep. Nutrition Abstracts and Reviews (Série B), v.60, n.9, p.653-664, 1990.

SCHOLL, J.M.; LOBATO, J.F.P.; BARRETO, I.L. Improvement of pastures by direct seeding into native grass in southern Brazil with oats, and with nitrogen supplied by fertilizer or arrow leaf clover. Turrialba, v.26, n.2, p.144-149, 1976.

SAWYER, G.J.; BARKER, D.J.; MORRIS, R.J. Performance of young breeding cattle in commercial herds in the south-west of Western Australia. 1. Liveweight, body condition, conception and fertility in heifers. Australian Journal Experimental Agriculture, v.31, n.4, p.431-441, 1991.

SCHILLO, K.K. Effects of dietary energy on control of luteinizing hormone secretion in cattle and sheep. Journal of Animal Science, v.70, n.12, p.1271-1282, 1992.

SEMMELMANN, C.E.N.; LOBATO, J.F.P.; ROCHA, M.G. Efeito de sistemas de alimentação no ganho de peso e desempenho reprodutivo de bezerras Nelore acasaladas aos 17/18 meses. Revista Brasileira de Zootecnia, v.30, n.3, p.835-843, 2001.

SIMEONE, A.; LOBATO, J.F.P. Efeitos da carga animal em campo nativo e do controle da amamentação no desenvolvimento de bezerros mestiços até um ano de idade. Revista Brasileira de Zootecnia, v.27, n.1, p.179-185, 1998 .

STEEL, R.G.D.; TORRIE, J.H. Bioestadística: Principios y Procedimientos. Cidade do México: McGraw Hill, 1989. 622p.

TANURE, S.; LOBATO, J.F.P. Natural and improved natural pastures on the reproductive performance of first-calf beef cows. Revista Brasileira de Zootecnia, v.40, n.3, p.690-699, 2011.

VAN SOEST, P.J. Nutritional ecology of ruminant. 2.ed. New York: Cornell University Press, 1994. 476p.

VAZ, R.Z.; LOBATO, J.F.P. Efeito da idade de desmame no desempenho reprodutivo de novilhas de corte expostas à reprodução aos 13/15 meses de idade. Revista Brasileira de Zootecnia, v.39, n.1, p.142-150, 2010a.

VAZ, R.Z.; LOBATO, J.F.P. Efeito da idade de desmame no desenvolvimento de novilhas de corte até os 14/15 meses de idade. Revista Brasileira de Zootecnia, v.39, n.2, p.289-298, 2010 b.

VAZ, R.Z.; LOBATO, J.F.P.; RESTLE, J. Influence of weaning age on the reproductive efficiency of primiparous cows. Revista Brasileira de Zootecnia, v.39, n.2, p.299-307, 2010.

VIEIRA, A.; LOBATO, J.F.P.; CORREA, E.S. et al. Desenvolvimento e desempenho reprodutivo de novilhas Nelore criadas a pasto nos cerrados do Centro-Oeste brasileiro. Revista Brasileira de Zootecnia, v.35, n.1, p.186-192, 2006. 